\title{
ДИНАМІКА РІЗНОМАНІТТЯ ТРАВ'ЯНО-ЧАГАРНИЧКОВОГО ЯРУСУ ПІСЛЯ СУЦІЛЬНИХ РУБАНЬ ДУБОВИХ ЛІСІВ ПРИРОДНОГО ПОХОДЖЕННЯ ТА СТВОРЕННЯ КУЛЬТУР ДУБА У ВОЛОГИХ СУГРУДАХ ЖИТОМИРСЬКОГО ПОЛІССЯ
}

\begin{abstract}
Досліджено флористичний склад та видову подібність трав'яно-чагарничкового ярусу рослинних угруповань / фітоценозів різного віку на місці суцільно-лісосічних рубань субклімаксових дубових лісів природного походження та створення культур дуба на зрубах (Житомирське ОУЛМГ, ДП "Лугинське ЛГ", Дивлинське лісництво, ДП "Баранівське ЛМГ", Баранівське лісництво). На 36 ділянках виконано геоботанічні описи (вікові категорії: 1 рік, 2 роки, 3 роки; 7, 10, 20-120 років) та визначено видову подібність трав'яно-чагарничкового ярусу цих груп за індексом Сьоренсена-Чекановського. Виявлено, що на місці зрубів упродовж 1-3 років формуються динамічні рослинні угруповання зі залишками лісових видів та значною участю світлолюбних рудеральних і лучних видів. Після змикання крон молодого деревостану (після 10 років) флористичний склад та ценотична будова фітоценозів поступово відновлюються, і в лісових культурах дуба звичайного після 40 років параметри видового різноманіття є подібними до таких, характерних для вихідних субклімаксових ценозів. Починаючи 3 10 років (періоду змикання крон), спостерігається висока видова подібність флористичного складу трав'яно-чагарничкового ярусу культур дуба з усіма віковими категоріями ценозів після змикання крон деревостану. Флористична подібність ценозів після періоду змикання з динамічними рослинними угрупованнями перших вікових груп є низькою. Ценотична будова лісових фітоценозів (ярусна, синузіальна) відновлюється після 30 років.
\end{abstract}

Ключові слова: зруби; відновлювальна сукцесія; рослинні угруповання; фіценози; індекс Сьоренсена-Чекановського.

Вступ. Після суцільних рубань зазвичай на зрубах створюють лісові культури, при цьому обробіток грунту є одним із головних чинників успішного вирощування високопродуктивних і біологічно стійких деревостанів, зокрема, дуба звичайного. Водночас, його результатом $€$ істотне порушення грунтово-рослинного покриву, що закономірно позначається на динаміці видового складу рослинних угруповань на зрубах. В умовах переважання в Україні суцільних рубань головного користування вивчення відновлювальних сукцесій на зрубах та у подальший період $\epsilon$ науковим підгрунтям для розроблення конкретних заходів зі сталого лісокористування [12]. Саме тому вивчення відновлення біорізноманіття дубових лісів вологих сугрудів $\epsilon$ актуальним.

Об'єкт дослідження - флористичний склад та ценотична будова ценозів/угруповань у лісових культурах дуба різного віку після суцільно-лісосічного рубання.

Предмет дослідження - динаміка флористичного складу та ценотичної будови ценозів/угруповань у лісових культурах дуба різного віку.

Метою дослідження є аналіз динаміки флористичного складу та ценотичної будови несформованих рослинних угруповань та фітоценозів під час відновлювальної сукцесії на місці суцільно-лісосічного рубання та створення лісових культур дуба.
Завдання дослідження: вивчення видового складу угруповань/ценозів у лісових культурах дуба різного віку під час відновлювальних сукцесій; аналіз видової подібності трав'яно-чагарничкового ярусу в лісових культурах дуба різного віку; дослідження відновлення ценотичної (ярусної та синузіальної) структури фітоценозів.

Наукова новизна дослідження полягає в тому, що вперше для рівнини України вивчено динаміку відновлення флористичного складу та ценотичної будови ценозів/угруповань у лісових культурах дуба різного віку після суцільно-лісосічного рубання у вологому грабово-дубово-сосновому сугруді.

Практична значущість - отримані результати дають змогу оцінити успішність відновлення лісових фітоценозів після суцільно-лісосічного рубання, збереження фіторізноманіття, відповідність угруповань, які формуються, вихідним субклімаксовим ценозам.

Матеріали і методи дослідження. Пробні площі у вологому сугруді закладено за стандартною геоботанічною методикою [20] у ДП "Лугинське ЛГ", Дивлинському лісництві та ДП "Баранівське ЛМГ", Баранівському лісництві. Контролем були субклімаксові дубові фітоценози природного походження. На місці суцільнолісосічних рубань для кожної вікової категорії фітоценозів/рослинних угруповань (1 рік, 2 роки, 3 роки; 7, 10,

\section{Інформація про авторів:}

Іванюк Irор Дмитрович, канд. с.-г. наук, доцент, директор. Email: mltk2010@gmail.com

Цитування за ДСТУ: Іванюк І. Д. Динаміка різноманіття трав'яно-чагарничкового ярусу після суцільних рубань дубових лісів природного походження та створення культур дуба у вологих сугрудах Житомирського Полісся. Науковий вісник НЛтУ України. 2020, т. 30, № 1. С. 33-38.

Citation APA: Ivanyuk, I. D. (2020). Dynamics of diversity of grass - dwarf-shrub layer after clear-cuttings in oak forests of natural origin and creation of oak cultures in wet sugruds of Zhytomyr Polissya. Scientific Bulletin of UNFU, 30(1), 33-38.

https://doi.org/10.36930/40300105 
$20,40,60,80,90,100,120$ років) закладено по три пробних площі - всього 36 шт. Залежно від складності ценозу, вони мали розмір від $625 \mathrm{~m}^{2}$ до 1 га. На них, за загальноприйнятою методикою [6], виконано повні геоботанічні описи.

Для оцінювання видової подібності рослинних угруповань різного віку використано загальноприйнятий показник - індекс Сьоренсена-Чекановського [9]. Його визначали лише для трав'яно-чагарничкового ярусу як найбільш флористично багатого та динамічного у лісовій рослинності. Для нього розроблено кількісні межі [9]: величина менше ніж 0,50 - видова подібність низька, більше як 0,50 - висока.

Індекс Сьоренсена-Чекановського визначаємо за такою формулою

$$
\text { Iвn }=2 C / A+B,
$$

де: $I_{6 n}-$ індекс Сьоренсена-Чекановського; $C$ - кількість спільних видів рослинних угруповань для двох пунктів; $A$ і $B$ - загальна кількість видів рослин, виділених із першого (А) та другого (В) пунктів дослідження.

Аналіз літературних джерел. Відновлювальні сукцесії рослинного покриву після суцільно-лісосічних рубань вивчено для хвойних лісів Фінляндії [18], мішаних лісів Канади [2], смерекових лісів тайгової зони Росії [3]. Показано, що найбільше видове різноманіття трав'яно-чагарничкового ярусу спостерігається на місці суцільних зрубів упродовж перших трьох років. Зроблено висновок про істотний вплив флористичного складу та ценотичної будови стиглих материнських лісових фітоценозів на рослинні угруповання, які розвиваються протягом відновлювальних сукцесій. В.В.Маврищев [8] розглянув сукцесії рослинності на місці суцільних зрубів у широколистяно-смерекових лісах Білорусі. Він відзначив, що під час відновлювальних сукцесій через ряд послідовних динамічних фаз вже у віці лісових культур 30-35 років формуються лісові фітоценози, близькі за флористичним складом до вихідних ценозів, з вираженою ценотичною будовою.

В Україні проаналізовано відновлювальні сукцесії трав'яно-чагарничкового ярусу зрубів рівнинних букових лісів Опілля [13], ялицево-букових лісів Прикарпаття [11], соснових лісів Українського Полісся [15, 16, 19]. Продемонстровано, що на зрубах переважають анемохорні види - $27 \%$ флористичного складу, значною була участь антропохорних видів - 25 \%. Зроблено висновок про те, що протягом початкових стадій відновлювальних сукцесій формуються найбільш флористично багаті угруповання, в яких роль лісових видів - мінімальна, натомість переважають бур'янові та світлолюбні лучні види.

Метод побудови матриць індексу видової подібності для аналізу відновлювальних сукцесій у культурах сосни різного віку застосували українські дослідники [15, $16,19]$. Показано, що видова подібність соснових фітоценозів у віці 85, 105 та 125 років є високою; однорічні та дворічні культури сосни характеризувалися низькою видовою подібністю з рештою вікових категорій.

У дубових лісах сугрудів у Житомирському Поліссі подібні дослідження не проводили.

Результати дослідження. Субклімаксовими фітоценозами у вологих грабово-дубово-соснових сугрудах $\left(\mathrm{C}_{3}\right.$ гдс) Житомирського Полісся $є$ дубові ліси крушиново-трясучковидноосокові (Quercetum (roboris) franguloso (alni) caricosum (brizoides)) у віці 120 років [4]. Їхній деревостан одноярусний, 3 дуба звичайного (Quercus robur L.), як домішка трапляються сосна звичайна (Pinus sylvestris L.), осика (Populus tremula L.), береза повисла (Betula pendula Roth.). II ярус деревостану формує граб звичайний (Carpinus betulus L.). Підлісок зімкнутістю 0,5-0,6 складається із крушини ламкої (Frangula alnus Mill.) $(0,3-0,4)$ та горобини звичайної (Sorbus aucuparia L.).

Трав'яно-чагарничковий ярус із проективним покриттям 85-90 \%. Домінує в ньому осока трясучковидна (Carex brizoides L.) (65-70 \%). Постійними видами є: opляк звичайний (Pteridium aquilinum (L.) Kuhn) - 5\%, конвалія звичайна (Convallaria majalis L.) - $5 \%$, суниці лісові (Fragaria vesca L.) - 1 \% та ін. Для цього ценозу характерною є синузія весняних ефемероїдів, яка має проективне покриття 35-50\% і складається з анемони дібровної (Anemone nemorosa L.). Видова насиченість фітоценозу дорівнює 39 видам рослин, зокрема, в ньому зростали види, занесені до Червоної книги України [14] - лілія лісова (Lilium martagon L.) та коручка морозниковидна (Epipactis helleborine (L.) Crantz).

Внаслідок суцільно-лісосічного рубання головного користування в цьому фітоценозі помітні зміни екологічних умов - на зрубі відбулося повне освітлення нижніх ярусів лісової рослинності, часткове порушення лісової підстилки та її перемішування з верхніми шарами гумусово-елювіального горизонту грунту, масове занесення насіння бур'янів.

У перший рік після суцільного рубання утворюються динамічні трав'яні угруповання зі залишками підліску, підросту деревних порід, а також світлолюбних видів трав'яно-чагарничкового ярусу материнського фітоценозу. 3 лісових видів зберігаються: осока трясучковидна $-15 \%$, орляк звичайний $-1 \%$, ожика волосиста (Luzula pilosa L.), зірочник лісовий (Stellaria holostea L.). Внаслідок занесення насіння у досліджуваному угрупованні масово трапляються малорічні рудеральні види: жабрій звичайний (Galeopsis tetrahit L.) - $5 \%$, жабрій двогубий (Galeopsis bifida Boenn) - од., коніза канадська (Conyza canadensis (L.) Cronq.) - 5 \%, череда листяна (Bidens frondosa L.) - 3 \%, фалакролома північна (Phalacroloma septentrionalis (Fernold. et Wiegand) Tzvelev) - $3 \%$, еректитес нечуйвітровий (Erechtites hieracifolia (L.) Raf. ex DC) - 5 \%. 3 перерахованих вище рудеральних видів чотири останніх є інвазійними адвентивними видами північноамериканського походження. В однорічному віці динамічні рослинні угруповання характеризуються найбільшим флористичним багатством, адже включають 83 види. Цей результат добре корелює з висновками Ю. В. Сірука $[16,17]$, отриманими для зрубів соснових суборів Житомирського Полісся. Також характерною рисою цих рослинних угруповань $є$ повне знищення ценотичної структури, притаманної вихідним лісовим фітоценозам.

На 2-річних зрубах зазвичай вже створені лісові культури дуба звичайного, рядами, у борозни. На цих ділянках формуються динамічні рослинні угруповання, подібні до таких в однорічному віці. Уже на другий рік 3 флористичного складу угруповань зникає частина лісових видів, які ще зберігалися на однорічних зрубах: конвалія звичайна, купина запашна (Polygonatum odoratum (Mill.) Druce), фіалка запашна (Viola odorata L.), ранник вузлуватий (Scrophularia nodosa L.) та ін. Інша частина лісових видів зменшує проективне покриття 
навіть порівняно з 1-річними зрубами: осока трясучковидна - від 15 до $3 \%$, орляк звичайний - від 5 до $1 \%$. Флористична насиченість зменшується до 64 видів. Як і в рослинних угрупованнях 1 року, у 2-річних угрупованнях провідну роль у формуванні травостою відіграють рудеральні види, які збільшують проективне покриття: жабрій звичайний - $8 \%$, латук списовидний (Lactuca serriola L.) - 1 \%, коніза канадська - $10 \%$, череда листяна - $5 \%$, еректитес нечуйвітровий $-8 \%$. Отож, інвазійні адвентивні північноамериканські види у 2-річних рослинних угрупованнях мають сумарне проективне покриття близько 30 \%. Також збільшується проективне покриття лучних видів: ожики блідої ( $L u$ zula pallescens Sw.) - $1 \%$, льонку звичайного (Linaria vulgaris L.) - $1 \%$ та ін. У 2-річних рослинних угрупованнях ценотична будова (ярусна та синузіальна) практично відсутня.

У 3-річних угрупованнях зберігаються окремі куртини підліску, які формують крушина ламка, горобина звичайна, малина звичайна (Rubus idaeus L.), а також підросту деревних порід - дуба звичайного, осики, яблуні лісової (Malus sylvestris Mill.), граба звичайного тощо. 3 флористичного складу ценозу продовжують випадати лісові види, зокрема: орляк звичайний, костяниця (Rubus saxatilis L.), куничник очеретяний (Calamagrostis arundinacea (L.) Roth) та ін. Інша частина лісових видів у цих угрупованнях відновлюється переважно під наметом підліску та підросту: купина запашна, буквиця лікарська (Betonica officinalis L.), ранник вузлуватий, чина чорна (Lathyrus niger (L.) Bernh.) тощо. Як і в попередній період після суцільної рубки, у 3-річних рослинних угрупованнях значну роль у формуванні травостою відіграють рудеральні види, зокрема, такі, як: жабрій двогубий, коніза канадська, череда листяна, проективне покриття яких зменшується. Для 3-річних рослинних угруповань характерною є відсутність ценотичної структури, флористична насиченість становить 54 види рослин.

Високу динамічність рослинного покриву протягом ініціальних стадій відновлювальних сукцесій на місці суцільних зрубів також наводили вчені для інших регіонів та типів зрубів $[5,7]$.

У подальший період відбувається поступове змикання крон підросту деревних порід та культур дуба звичайного, розростання підліску та збільшення його зімкнутості, що позначається на флористичному складі трав'яно-чагарничкового ярусу. Так, вже у 7-річному віці зімкнутість крон молодого деревного ярусу дорівнює 0,6-0,7(0,8), куртини підросту деревних порід змикаються 3 рядами культур дуба звичайного. Тоді ж зростає і зімкнутість підліску - від поодиноких примірників та невеликих біогруп у віці 3 роки до 0,50 у віці 7 років. До його складу входять крушина ламка - 0,30, горобина звичайна $-0,10$, малина звичайна $-0,10$. Видовий склад підросту деревних порід стає значно багатшим, порівняно 3 3-річними угрупованнями. До нього входять молоді деревця дуба звичайного, осики, берези повислої, клена гостролистого (Acer platanoides L.) та ін. Трав'яно-чагарничковий ярус 7-річних культур дуба істотно змінюється, порівняно з 3-річними ділянками: збільшується його проективне покриття від 50 \% у 3річних ділянках до $90 \%$ у 7-річних, відновлюється участь лісових видів-домінант трав'яно-чагарничкового ярусу: орляка звичайного - від $0 \%$ до $5 \%$, осоки трясучковидної - від $5 \%$ до $75 \%$. Постійними видами у цьому ярусі є: молінія голуба (Molinia caerulea (L.) Moench) $-3 \%$, зірочник лісовий $-1 \%$, ожика волосиста, купина запашна, фіалка запашна, буквиця лікарська тощо. Більшість світлолюбних рудеральних та лучних видів у 7-річних культурах дуба випадають зі складу угруповання внаслідок збільшення зімкнутості крон. Видова насиченість рослинних угруповань у 7-річному віці зменшується до 41 виду. У цьому віці поступово відновлюється ярусна будова, але синузіальна будова ще відсутня. У віці 8-9 років відбувається змикання крон молодого деревостану лісових культур дуба звичайного 3 природним поновленням i переведення ділянок у вкриту лісом площу. Зімкнутість крон деревостану сягає 0,80-0,85. До його складу входять практично всі види, які траплялися у вихідних 120-річних фітоценозах до рубання: дуб звичайний, осика, береза повисла, клен гостролистий, граб звичайний та ін. [4].

Підлісок за флористичним складом і ценотичною будовою також є подібним до 90-120-річних ценозів. Його зімкнутість зазвичай дорівнює 0,50 , він складається 3 типових видів: крушини ламкої-0,30, горобини звичайної - 0,10 тощо. Важливі перебудови відбуваються у 10-річних культурах дуба звичайного у трав'яно-чагарничковому ярусі - значно збільшується його видова насиченість - від 41 виду у 7-річних культурах до 61 виду у 10-річних. Відбувається цей процес переважно завдяки появі типових лісових видів: конвалії звичайної, щитника шартрського (Dryopteris carthusiana (Vill.) F. W. Fuchs), звіробою гірського, ранника вузлуватого та ін. Внаслідок збільшення зімкнутості крон деревостану з флористичного складу у цей період продовжують випадати світлолюбні рудеральні та лучні види, ценотична будова фітоценозу майже відновлюється. Зокрема, ярусна будова включає ярус деревостану, підлісок, підріст і три під'яруси трав'яно-чагарничкового ярусу, але синузіальна будова у культурах дуба 10-річного віку відсутня. На значній подібності флористичного складу фітоценозів молодих лісових культур після періоду змикання крон до вихідних материнських ценозів наголошували й інші дослідники [1, $10,12,13]$.

У 20-річному віці деревостан збільшує зімкнутість до 0,9-1,0, його видовий склад $є$ подібним до вихідних 120-річних ценозів. Зімкнутість підліску стабілізується на рівні 0,40-0,50, його флористичний склад також $\epsilon$ подібним до вихідних фітоценозів. Основу підліску створюють крушина ламка - 0,40 та горобина звичайна - до 0,10. Проективне покриття трав'яно-чагарничкового ярусу стабілізується на рівні 80-90\%, а кількість видів у ньому - на рівні 30-45 видів. Як і у вихідних материнських фітоценозах, у трав'яно-чагарничковому ярусі 20-річних лісових культур дуба домінує осока трясучковидна - $65 \%$, значну участь у цьому ярусі беруть: орляк звичайний $-5-10 \%$, моління голуба $-5 \%$, зірочник лісовий - 3-5 \%, конвалія звичайна - 5-8 \%, костяниця (Rubus saxatilis L.) - 1-5 \% тощо. 3 флористичного складу трав'яно-чагарничкового ярусу випадають практично всі світлолюбні рудеральні та лучні види. Ценотична структура фітоценозу добре виявлена, відновлюється ярусна будова, до складу якої входять деревостан, підлісок, підріст і три під'яруси трав'яно-чагарничкового ярусу; починає відновлюватися синузіальна будова з'являються невеликі біогрупи весняного ефемероїда анемони дібровної - 1-3\%. 
У лісових культурах дуба звичайного, віком 40, 60, 80, 90, 100 років відбувається подальше відновлення як флористичного складу, так і ценотичної будови фітоценозу. Характерними $є$ певні коливання флористичної насиченості фітоценозів - від 43-57 видів у віці 4047 років до 43-56 видів у віці 60-65 років, 40-65 видів у віці 80-83 років, 37-50 видів у віці 90-93 років та 47 видів у віці 100 років. Породний склад деревостану утворюють дуб звичайний, який формує I ярус деревостану, а також осика, береза, клен гостролистий. II ярус деревостану створює граб звичайний. Флористичний склад та зімкнутість підліску в лісових культурах дуба після 20-річного віку змінюється слабо і є подібним до вихідних ценозів до рубки. Трав'яно-чагарничковий ярус лісових культур у віці 40-100 років відзначається значним проективним покриттям. Його величина є максимальною у віці лісових культур 40-80 років - 85\%, зменшуючись до $65 \%$ у віці 93 років та до $50 \%$ у віці 100 років. Трав'яно-чагарничковий ярус складається 3 3-х під'ярусів. Перший під'ярус, заввишки 80-100 см, формують орляк звичайний - 3-5\%, моління голуба $5 \%$, бір розлогий (Milium effusum L.) та ін. У II, основному під'ярусі, заввишки 20-50 см, трапляються осока трясучковидна - 55-75\%, чорниці (Vaccinium myrtillus L.) - 5-10\%, конвалія звичайна - 3-5 \%, зірочник лісовий - 1-3 \% та ін. III під'ярус, заввишки 5-10 см, утворюють: одинарник лісовий (Trientalis europaea L.), вероніка лікарська (Veronica officinalis L.), фіалка запашна, осока гірська (Carex montana L.) тощо. Описані вище під'яруси трав'яно-чагарничкового ярусу подібні до таких вихідних 120-річних ценозів. Починаючи 3 40річного віку, у лісових культурах дуба трапляється лілія лісова - вид, занесений до Червоної книги [14], а з 60річного віку - інші червонокнижні види - коручка морозниковидна та гніздівка звичайна (Neottia nidus-avis (L.) Rich.). Починаючи з 40 років, у лісових культурах дуба добре виражена синузіальна будова. Навесні суцільним білим забарвленням проявляється синузія весняного ефемероїда анемони дібровної - 30-50 \%.

Обговорення отриманих результатів дослідження. У процесі відновлення рослинних угруповань на місці суцільних рубань головного користування закономірно проявляється динаміка їх флористичного складу. Відповідні дані наведено у матриці видової подібності трав'яно-чагарничкового ярусу рослинних угруповань різного віку (таблиця).

Таблиця. Матриця індексів видової подібності трав'яночагарничкового ярусу рослинних угруповань та фітоценозів різного віку на місці суцільних рубань субклімаксових дубових лісів природного походження

\begin{tabular}{|c|c|c|c|c|c|c|c|c|c|c|c|}
\hline $\begin{array}{c}\text { Вік, } \\
\text { років }\end{array}$ & 1 & 2 & 3 & 7 & 10 & 20 & 40 & 60 & 80 & 90 & 100 \\
\hline 2 & $\mathbf{0 , 8 0}$ & & & & & & & & & & \\
\hline 3 & $\mathbf{0 , 7 2}$ & $\mathbf{0 , 7 4}$ & & & & & & & & & \\
\hline 7 & 0,48 & 0,49 & 0,48 & & & & & & & & \\
\hline 10 & $\mathbf{0 , 6 0}$ & $\mathbf{0 , 5 0}$ & $\mathbf{0 , 5 8}$ & $\mathbf{0 , 5 8}$ & & & & & & & \\
\hline 20 & 0,49 & 0,41 & 0,46 & $\mathbf{0 , 5 1}$ & $\mathbf{0 , 7 6}$ & & & & & & \\
\hline 40 & 0,47 & 0,39 & 0,44 & 0,49 & $\mathbf{0 , 7 2}$ & $\mathbf{0 , 7 9}$ & & & & & \\
\hline 60 & 0,42 & 0,41 & 0,32 & 0,46 & $\mathbf{0 , 6 4}$ & $\mathbf{0 , 7 5}$ & $\mathbf{0 , 7 3}$ & & & & \\
\hline 80 & 0,45 & 0,36 & 0,40 & 0,41 & $\mathbf{0 , 7 6}$ & $\mathbf{0 , 8 0}$ & $\mathbf{0 , 8 5}$ & $\mathbf{0 , 7 7}$ & & & \\
\hline 90 & 0,42 & 0,39 & 0,35 & $\mathbf{0 , 5 3}$ & $\mathbf{0 , 7 1}$ & $\mathbf{0 , 7 8}$ & $\mathbf{0 , 7 6}$ & $\mathbf{0 , 8 5}$ & $\mathbf{0 , 8 6}$ & & \\
\hline 100 & 0,35 & 0,32 & 0,37 & 0,45 & $\mathbf{0 , 7 1}$ & $\mathbf{0 , 7 3}$ & $\mathbf{0 , 7 9}$ & $\mathbf{0 , 7 0}$ & $\mathbf{0 , 7 8}$ & $\mathbf{0 , 7 8}$ & \\
\hline 120 & 0,27 & 0,28 & 0,31 & 0,44 & $\mathbf{0 , 5 1}$ & $\mathbf{0 , 5 5}$ & $\mathbf{0 , 6 4}$ & $\mathbf{0 , 5 2}$ & $\mathbf{0 , 6 2}$ & $\mathbf{0 , 6 6}$ & $\mathbf{0 , 6 4}$ \\
\hline
\end{tabular}

Подібність флористичного складу трав'яно-чагарничкового ярусу материнських 120-річних насаджень 3 рослинними угрупованнями після суцільного рубання характеризувалася чітко вираженою динамікою (див. таблицю). Загальною закономірністю для цієї вікової категорії є низька видова подібність 3 динамічними рослинними угрупованнями 1-7 років (індекс СьоренсенаЧекановського - $I_{6 n}$ знаходився у діапазоні $\left.0,27-0,44\right)$. При цьому спостерігали зростання його значень зі збільшенням віку рослинних угруповань. Подібні дані для соснових лісів Західного Полісся раніше отримав В. Д. Шкудор [15], а для соснових лісів Житомирського Полісся - Ю. В. Сірук [16]. Визначальним чинником відновлення видового складу трав'яно-чагарничкового ярусу є зімкнутість крон деревного ярусу. Вже у віці 10 років значення $I_{\text {вn }}$ перевищує 0,50 , що свідчить про високу подібність флористичного складу трав'яно-чагарничкового ярусу до 120-річних ценозів. Зокрема, у 10-річних культурах відразу після змикання крон значення $I_{6 n}$ дорівнювало 0,51 ; у 20-річних культурах 0,55 ; у 40-річних - 0,64, у 80-річних - 0,62. Так було виявлено, що видова подібність трав'яно-чагарничкового ярусу материнських 120-річних ценозів та ценозів після змикання крон деревостану збільшується 3 підвищенням віку лісових культур.

Динаміка видової подібності трав'яно-чагарничкового ярусу 1-річних рослинних угруповань має специфічний характер. Зокрема, видова подібність 1-річних угруповань $\epsilon$ дуже високою 3 угрупованнями 2-х та 3-х років $\left(I_{6 n}=0,80-0,72\right)$ відповідно. У 7-річному віці значення $I_{6 n}=0,48$ засвідчило низьку видову подібність 3 1-річними угрупованнями, однак у віці лісових культур 10 та 20 років видова подібність 31 -річними угрупованнями була високою $\left(I_{6 n}=0,60-0,51\right)$, що, вірогідно, зумовлене значною участю лісових помірно світлолюбних видів у флористичному складі культур цих вікових груп. Загальною закономірністю є зменшення видової подібності 1-річних рослинних угруповань 3 лісовими культурами всіх вікових категорій після 40 років, коли флористичний склад трав'яно-чагарничкового ярусу майже відновлюється до клімаксового. Так, значення $I_{6 n}$ дорівнювало 0,47 у 40-річних культурах, 0,42- у 60річних, 0,45-у 80-річних. У 2-річних рослинних угрупованнях також спостерігали подібний випадок: найвищу видову подібність флористичного складу виявлено 3 1-річними та 3-річними угрупованнями, значення $I_{6 n}$ дорівнювало 0,80 та 0,74 відповідно.

Важливо зазначити, що перед віком змикання крон деревостану (вік -7 років) та безпосередньо після нього (вік 10 років) видова подібність 2-річних рослинних угруповань була також високою, значення $I_{6 n}$ дорівнювало в обох вікових категоріях 0,50. Отримані нами дані узгоджуються з результатами, які навели у своїх працях [19] інші дослідники.

Видова подібність 2-річних рослинних угруповань $\epsilon$ незначною 3 усіма рослинними угрупованнями після 20 років, значення $I_{6 n}$ знаходилися у діапазоні 0,41-0,28. При цьому загальною закономірністю було зменшення видової подібності 2-річних рослинних угруповань 3 рослинними угрупованнями після 20 років зі збільшенням їхнього віку. Динаміка видової подібності трав'яночагарничкового ярусу 3-річних рослинних угруповань також є подібною до описаної вище.

Семирічні рослинні угруповання формуються у період змикання крон деревостану. Саме в цей період відбувається випадання з флористичного складу більшості світлолюбних рудеральних, а також лучних видів, роз- 
ростання типових лісових видів флори. Дані таблиці свідчать, що у 7-річних рослинних угруповань видова подібність флористичного складу з 1-річними, 2-річними та 3-річними угрупованнями була незначною, значення $I_{6 n}$ знаходилися у діапазоні $0,48-0,49$. Однак, з 10 річними та 20-річними угрупованнями видова подібність була високою, значення $I_{6 n}-0,51-0,58$. 10-річні фітоценози, які формуються у лісових культурах дуба після періоду змикання крон деревостану, мають виражену динаміку видової подібності, зокрема, видова їхня подібність 3 рослинними угрупованнями 1-3 років $\epsilon$ низькою $\left(I_{6 n}=0,48-0,49\right)$. Зумовлено це переважно випаданням світлолюбних рудеральних, лучних та узлісних видів зі складу трав'яно-чагарничкового ярусу у процесі змикання крон молодого деревостану. Видова подібність 10-річних фітоценозів із фітоценозами у віковому діапазоні 20-90 років була високою $\left(I_{8 n}=0,53-\right.$ 0,76), однак видова подібність 10-річних фітоценозів із фітоценозами у віковому діапазоні 100-120 років була низькою $\left(I_{6 n}=0,44-0,45\right)$. Це свідчить про значні відмінності флористичного складу 10-річних лісових культур дуба з клімаксовими фітоценозами.

У віці 20 років властивими $є$ високі значення видової подібності з усіма рослинними угрупованнями, починаючи з 7-річного віку. Величини індексу видової подібності 20-річних ценозів коливалися від 0,51 у 7-річних культурах до 0,75 у 60 -річних та 0,80 у 80-річних. Спостерігали високу видову подібність 20-річних ценозів 3 субклімаксовими і клімаксовими, віком 100 та 120 років $\left(I_{6 n}=0,73-0,55\right)$. Флористична подібність 20 річних ценозів 3 динамічними рослинними угрупованнями перших вікових груп була невисокою $\left(I_{6 n}=0,41-\right.$ $0,49)$, що зумовлено появою лісових видів у флористичному складі ценозів та майже повним зникненням світлолюбних рудеральних, лучних та узлісних видів внаслідок змикання крон деревостану та розростання підліску та підросту.

Аналогічна динаміка флористичної подібності трав'яно-чагарничкового ярусу була характерною також для лісових ценозів 40, 60, 80, 90, 100-річного віку. Дані таблиці дають змогу стверджувати, що видова подібність флористичного складу трав'яно-чагарнирчкового ярусу культур дуба після 40 років з усіма віковими категоріями після змикання крон деревостану була високою, що свідчить про відновлення видового складу трав'яно-чагарничкового ярусу.

\section{Висновки:}

1. На місці суцільно-лісосічних рубань у дубових лісах вологих сугрудів упродовж 1-3 років після рубання формуються динамічні рослинні угруповання зі залишками лісових видів та значною участю рудеральних та лучних видів. Після змикання крон молодого деревостану (після 10 років) флористичний склад та ценотична будова фітоценозів поступово відновлюються, і в лісових культурах дуба звичайного після 40 років ці параметри $є$ подібними до таких, характерних для субклімаксових ценозів дубових лісів.

2. Починаючи з 10 років (періоду змикання крон), спостерігається висока видова подібність флористичного складу трав'яно-чагарничкового ярусу культур дуба 3 усіма віковими категоріями ценозів після змикання крон молодого деревостану, а також клімаксовими фітоценозами. Флористична подібність ценозів після періоду змикання 3 динамічними рослинними угрупованнями перших вікових груп є невисокою.
3. Сучасна практика лісовідновлення після виконання суцільно-лісосічних рубань дубових лісів у вологих сугрудах із подальшим створенням лісових культур дуба звичайного і використанням природного поновлення сприяє задовільному відтворенню лісових фітоценозів, близьких за флористичним складом і ценотичною будовою до субклімаксових.

4. Після 40 років у лісових культурах дуба відновлюються популяції рідкісних видів рослин, занесених до Червоної книги України, - лілії лісової, коручки морозниковидної, гніздівки звичайної та ін.

\section{References}

1. Dymov, A. A. (2017). Influence of clear-cutting in boreal forests of Russia on soil cover: review. Pochvovedenie, 7, 787-798. [In Russian].

2. Garcia-Tejero, S., Spence, J. R., OHalloran, J., et al. (2018). Nutritional succession and clear-cutting as drivers of environmental heterogeneity and beta-diversity in North American boreal forests. Plos One, 11, 1.16-16.16.

3. Genikova, N. V., Toropova, E. V., \& Kryshen, A. M. (2016). Reaction of species of aboveground cover of spruce forest on cutting of tree canopy. Tr. Karelskoho nauchnoho centra RAN, 4, 92-99.

4. Hryn, F. O. (1971). Oak and broadleaves-oak forests. Roslynnist URSR. Lisy. Kyiv: Scientific thought. [In Ukrainian].

5. Keenan, R. J., \& Kimmins, J. P. (1993). The ecological effects of clear-cutting. Environmental Review, 1, 121-144.

6. Korchagin, A. A. (1964). Species (floristic) composition of plant communities and methods of its investigation. Polevaya geobotanica, 3, 39-59. Moscow, Leningrad: Science. [In Russian].

7. Lukashchuk, H. B. (2012). Dynamics of plant cenopopulations on clear-cuttings of Gorgany. Scientific Bulletin of UNFU, 22(8), 42-48.

8. Mavrichshev, V. V. (2009). Singenetic successions of vegetation on clear-cuttings of coniferous phytocenoses. (Ser. Biology). Vesti $B G P U$, 2, 39-43. [In Russian].

9. Odum, Yu. (1986). Ecology. (Vol. 2). Moscow: Mir, 376 p.

10. Orfanitsky, Yu. A., \& Orfanitskaya, V. G. (1971). Soil conditions of tayga clear-cuttings. Moscow: Lesnaya promyshlennost, $96 \mathrm{p}$. [In Russian].

11. Parpan, T. V. (2003). Secondary succession on clear-cuttings of fir-beech dendrocenoses of Carpathian. Ekolohiia $i$ noosferolohiia, 14(3-4), 29-32. [In Ukrainian].

12. Parpan, V. I., Shparyk, Yu. S., Parpan, T. V., et al. (2002). European basis of sustainable development and necessity its introduction in Ukrainian Carpathians. Lisovyi i myslyvskyi zhurnal, 4, 16 18. [In Ukrainian].

13. Parpan, V. I., Viter, R. M., Parpan, T. V., \& Tselen, Ya. P. (2003). Ecological succession of grass layer on clear-cuttings in flat beech forests of Ukraine. Scientific Bulletin of UNFU, 13(3), 135-142. [In Ukrainian].

14. Red Data Book of Ukraine. Plant world. (2009). Kyiv: Alterpres, 601 p. [In Ukrainian].

15. Shkudor, V. D. (2006). Increasing of durability and conservation of plant diversity of Scotch pine forests of Western Polissya of Ukraine. Kharkiv, 18 r. [In Ukrainian].

16. Siruk, Yu. V. (2012). Types of clear-cuttings and peculiarities of forest-recovery of Scotch pine in subors of Central Polissya. Kyiv, 20 p. [In Ukrainian].

17. Siruk, Yu. V. (2013). Dynamics of species diversity of living aboveground cover after clear-cuttings of the main use. Biolohichni doslidzhennia, 1-3. Zhytomyr: Polissia. [In Ukrainian].

18. Uotila, A. (2004). Vegetation patterns in managed and semi-natural boreal forests in eastern Finland and Russian Karelia. Academic dissertation. Faculty of Forestry, University of Joenssuu, $48 \mathrm{p}$.

19. Vedmid, M. M., Shkudor, V. D., \& Buzun, V. O. (2008). Restoration of natural forest stands of Western Polissya. Zhytomyr: Polissia. [In Ukrainian].

20. Yunatov, A. A. (1964). Establishment of ecological profiles and experimental plots. Polevaya geobotanica, 3, 9-35. Moscow, Leningrad: Science. [In Russian]. 


\section{DYNAMICS OF DIVERSITY OF GRASS - DWARF-SHRUB LAYER AFTER CLEAR-CUTTINGS IN OAK FORESTS OF NATURAL ORIGIN AND CREATION OF OAK CULTURES IN WET SUGRUDS OF ZHYTOMYR POLISSYA}

Experimental plots in wet hornbeam-oak-pine sugrud were established by standard methodology in Zhytomyr RMFHR, State Enterprise "Lugynske Forest Range", Dyvlyn forestry and State Enterprise "Baranivske Forest Hunting Range", Baranivske forestry. For each age category of phytocenoses/plant community (1 year old, 2 years old, 3 years old; 7, 10, 20, 40, 60, 80, 90, 100, 120 years old) were established 3 experimental plots - in total 36. Geobatanic relevés were performed on generally accepted technique. Species composition and projective cover of each species was noted, and for community as a whole - presence of layer and sinusial structure. For evaluation of floristic similarity of cenoses of different age index of Sjorensen-Chekanovsky was used. Obtained results showed that after conducting of clear-cuttings in oak forests of wet sugruds during 1-3 years dynamic plant communities form, with residuals of typical forest species and significant participation of heliophilous ruderal and meadow species. During this period index of floristic similarity of these dynamic plant communities with all age categories of cenoses after crowns closing is low $-0,31-0,48$. After closing of crowns of young tree canopy (after 10 years) floristic composition and cenotic structure of phytocenoses gradually recover, and in oak cultures after 40 years parameters of species diversity are similar for those, which are character for initial subclimax cenoses. Starting from 10 years old high similarity of floristic composition of grass - dwarf-shrub layer is observed in oak cultures with all age categories of cenoses after crowns closing. Corresponding values of index of Sjorensen-Chekanovsky were in diapason 0,510,86 ). Cenotic structure of forest phytocenoses (layers, sinusial) restores only in 30 -years old cenoses. It was found that in 40 -years old oak cultures populations of plant species inlisted to the Red Data Book of Ukraine restore - Liluim martagon L., Epipactis helleborine (L.) Crantz, Neottia nidus avis (L.) Rich. etc. Presented data allow us to conclude that modern reforestation practice after conducting of clear-cuttings of the main use in oak forests in wet sugruds following by creation of forest oak cultures accompanying of young tree undergrowth contributes to satisfactory restoration of forest cenoses similar on floristic composition and cenotic structure to subclimax ones. (Floristic composition and species similarity of grass - dwarf-shrub layer of plant communities/phytocenoses of different age were studied on the places of clear cuttings of subclimax oak forests of natural origin and creation of oak cultures on fellings (Zhytomyr RMFHR, State Enterprise "Luhynske Forest Range", Dyvlyn forestry; State Enterprise "Baranivske Forest Hunting Range", Baranivske forestry). Geobatanic relevés were performed on 36 experimental plots (age categories: 1 year, 2 years, 3 years; 7, 10, 20-120 years), and species similarity among these groups was calculated by index of Sjorensen-Chekanovsky. It was found that on the places of fellings during 1-3 years dynamic plant communities form with residuals of typical forest species and significant participation of heliophilous ruderal and meadow species. After closing of crowns of young tree canopy (after 10 years) floristic composition and cenotic structure of phytocenoses gradually recover, and in oak cultures after 40 years parameters of species diversity are similar for those, which are character for initial subclimax oak cenoses. Starting from 10 years old high similarity of floristic composition of grass - dwarf-shrub layer is observed in oak cultures with all age categories of cenoses after crowns closing. Corresponding values of index of Sjorensen-Chekanovsky were in diapason 0,51-0,86). Floristic similarity of cenoses after crowns closing with dynamic plant communities on initial age groups is low. It was shown that cenotic structure of forest phytocenoses (layers, sinusial) restores only after its age of 30 years).

Ключові слова: fellings; restore succession; plant communities; phytocenoses; Sjorensen-Chekanovsky index. 